\title{
Novel Chimeric Protein Vaccines Against Clostridium difficile Infection
}

OPEN ACCESS

Edited by:

Lee Mark Wetzler,

Boston University, United States

Reviewed by:

Pietro Speziale,

Università degli studi di Pavia, Italy

Owen Kavanagh,

York St. John University,

United Kingdom

${ }^{*}$ Correspondence:

Xingmin Sun

sun5@health.usf.edu

†These authors have contributed equally to this work

Specialty section:

This article was submitted to Vaccines and Molecular Therapeutics,

a section of the journal

Frontiers in Immunology

Received: 07 July 2018 Accepted: 02 October 2018 Published: 22 October 2018

Citation:

Wang S, Wang Y, Cai Y, Kelly CP and Sun $X$ (2018) Novel Chimeric Protein Vaccines Against Clostridium difficile Infection. Front. Immunol. 9:2440. doi: 10.3389/fimmu.2018.02440

\author{
Shaohui Wang ${ }^{1 \dagger}$, Yuanguo Wang ${ }^{1 \dagger}$, Ying Cai ${ }^{1}$, Ciaran P. Kelly ${ }^{2}$ and Xingmin Sun ${ }^{1 *}$ \\ ${ }^{1}$ Department of Molecular Medicine, Morsani College of Medicine, University of South Florida, Tampa, FL, United States, \\ ${ }^{2}$ Division of Gastroenterology, Department of Medicine, Beth Israel Deaconess Medical Center, Harvard Medical School, \\ Boston, MA, United States
}

Clostridium difficile infection (CDI) is the leading cause of world-wide nosocomial acquired diarrhea in adults. Active vaccination is generally accepted as a logical and cost-effective approach to prevent CDI. In this paper, we have generated two novel chimeric proteins; one designated Tcd169, comprised of the glucosyltransferase domain $(\mathrm{GT})$, the cysteine proteinase domain (CPD), and receptor binding domain (RBD) of TcdB, and the RBD of TcdA; the other designated Tcd169FI, which contains Salmonella typhimurium flagellin (sFliC) and Tcd169. Both proteins were expressed in and purified from Bacillus megaterium. Point mutations were made in the GT (W102A, D288N) and CPD (C698) of TcdB to ensure that Tcd169 and Tcd169FI were atoxic. Immunization with Tcd169 or Tcd169FI induced protective immunity against TcdA/TcdB challenge through intraperitoneal injection, also provided mice full protection against infection with a hyper-virulent $C$. difficile strain (BI/NAP1/027). In addition, inclusion of sFlic in the fusion protein (Tcd169FI) enhanced its protective immunity against toxin challenge, reduced $C$. difficile numbers in feces from Tcd169FI-immunized mice infected $C$. difficile. Our data show that Tcd169 and Tcd169FI fusion proteins may represent alternative vaccine candidates against CDI.

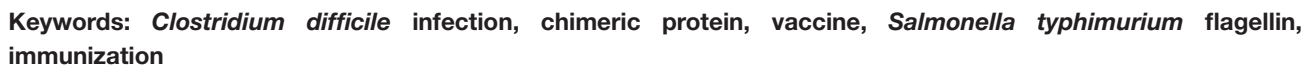

\section{INTRODUCTION}

Clostridium difficile (C. difficile) is a Gram-positive, spore-forming, toxin-producing and anaerobic bacillus that is transmitted through spore forms (1). It is the most common cause of nosocomial antibiotic-associated diarrhea (2-4). Symptoms of Clostridium difficile infection (CDI) range from diarrhea to intestinal inflammation/lesion and death, which are mainly caused by two protein toxins, toxin A (TcdA) and toxin B (TcdB) (5). Globally, CDI remains an urgent public health problem. In the United States, $C$. difficile is the most common healthcare-associated pathogen (6) with approximately half a million infections and more than 29,000 deaths attributable to $C$. difficile per year (7). A recent study showed that mean healthcare costs attributable to primary CDI were $\$ 24,205$ per patient, and patients with recurrent CDI had an additional $\$ 10,580$ in infectionrelated healthcare costs (8). Currently, standard therapy relies on treatment with vancomycin, metronidazole, or fidaxomicin (9-11), but none of which is fully effective, with up to a $35 \%$ recurrence rate (12). Treatment of recurrent CDI is one of the major challenges in the field (13-15). Active vaccination is generally accepted as a logical and cost-effective approach to prevent CDI, but more research is needed to determine the clinical benefits of the vaccines (16). Currently, no vaccine is licensed for the prevention of CDI. 
Since the major virulence factors of $C$. difficile are TcdA and $\mathrm{TcdB}$ (5), tremendous efforts have been made to develop C. difficile vaccines targeting both TcdA and TcdB (17-19). However, C. difficile survives in environment as spore forms, which are very stable, resistant to antibiotics and harsh conditions, and the root cause of recurrent CDI. Therefore, an ideal and effective $C$. difficile vaccine should target both toxins and $C$. difficile colonization with a goal to prevent toxin-mediated disease symptoms and reduce spore-mediated transmission. In this project, we aimed to construct chimeric proteins containing immunodominant domains/fragments of both toxins and component, which is effective in inducing anti- $C$. difficile colonization immune responses.

Both toxins share similar domain structures (20), including the $\mathrm{N}$ terminus catalytic glucosyltransferase domain (GT), the autoproteolytic cysteine proteinase domain (CPD), a central translocation domain (TM), and a C-terminal receptor-binding domain (RBD). Recent studies have indicated that the RBD of TcdB or TcdA can serve as excellent immunogens (20-24). In our previous study $(25,26)$, and consistent with others $(27,28)$, we indicated that the $\mathrm{N}$-terminus of $\mathrm{TcdB}$ was able to elicit a protective antibody response. We (25) and others (29) also indicated that CPD could play important roles in maintaining the native structure or epitope conformation of GTD. In this study, we generated a new chimeric protein, Tcd169, by fusing GT, CPD, and RBD of TcdB and RBD of TcdA. It has been reported that Salmonella typhimurium flagellin (sFliC) protects mice from death during CDI by delaying $C$. difficile growth in the gut (30). SFliC is known potent adjuvant, and is structurally similar to C. difficile flagellin FlicC (cFliC) (31). Therefore, we further fused Tcd169 with sFliC, generating Tcd169FI to construct a vaccine candidate targeting both toxins and $C$. difficile colonization/growth. In this communication, we evaluated and characterized the immunogenicity of protective efficacy of these two fusion proteins in vitro and in vivo (mouse).

\section{MATERIALS AND METHODS}

\section{Animals}

Wild-type C57BL/6 mice were purchased from Charles River Laboratories. Female C57BL/6 mice were housed under the same conditions at a semi-natural light cycle of $14 \mathrm{~h}: 10 \mathrm{~h}$ (light: dark) in a specific pathogen-free (SPF) environment. Mice receive water and food ad libitum. After infection with $C$. difficile, mice were housed in an infection room. All mouse studies followed the Guide for the Care and Use of Laboratory Animals of the National Institutes of health, and were approved by the Institutes Animal Care and Use Committee (IACUC) at University of South Florida under the protocol number IS00003756. All efforts were made to minimize suffering.

\section{Preparation of C. difficile Spores}

Sporulation of the C. difficile UK1 strain was induced in Clospore medium as described previously (32). Briefly, an overnight $20 \mathrm{ml}$ of $C$. difficile cultured in Columbia Broth was inoculated into $500 \mathrm{ml}$ of Clospore medium, and incubated for $1-2$ weeks at $37^{\circ} \mathrm{C}$ in an anaerobic incubator. The spore suspension was centrifuged at $10,000 \mathrm{~g}$ for $20 \mathrm{~min}$, and the pellet was washed five times with sterile water, and suspended in $10 \mathrm{ml}$ of $\mathrm{ddH}_{2} \mathrm{O}$. The spore suspension was heated at $60^{\circ} \mathrm{C}$ for $20 \mathrm{~min}$ to kill vegetative cells, and stored at $4^{\circ} \mathrm{C}$. The spore concentration was determined by serial dilution on TCCFA or BHI plates (33).

\section{Expression of Recombinant Fusion Proteins Tcd169 and Tcd169FI in Bacillus megaterium}

We constructed a recombinant fusion protein, containing the GT, CPD, and receptor binding domain (RBD) of TcdB and RBD of TcdA, bridged with a six-amino acid linker (GGSGGS), resulting in protein Tcd169. To generate a vaccine candidate targeting both toxins and $C$. difficile colonization/growth, we further fused Tcd169 with sFliC bridged with the six-amino acid linker (GGSGGS), resulting in protein Tcd169Fl. The chimeric DNA encoding Tcd169 or Tcd169FI was ligated into Bacillus megaterium expression vector pHis1525, which adds a C-terminal His-tag to the chimeric proteins. B. megaterium is a gram-positive environmental microbe. The protein expressed from B. megaterium system can be free of LPS. Tcd169 and Tcd169FI were purified from bacterial lysate by Ni-affinity chromatography followed by size exclusion chromatography (gel filtration) using Superdex 200 column (cat\# 28-9909-44, GE Health).

\section{Western Blot Analysis}

Purified Tcd169 and Tcd169FI proteins were subjected to $8 \%$ SDS-PAGE separation. Then, proteins were transferred onto the Nylon membrane. After blocking for $1 \mathrm{~h}$ at room temperature with $5 \%$ skim milk, the membrane was incubated overnight at $4^{\circ} \mathrm{C}$ with anti-TcdA, anti-TcdB, or anti-sFliC antibody (Cat: 629701, Biolegend, Bath, UK). After washing with PBST (PBS with $0.05 \%$ Tween), the membrane was incubated with horseradish peroxidase-conjugated secondary goat anti-mouse antibody (Cat: ab97023, Abcam, Cambridge, MA), the antibodyreactive bands were revealed by enhanced chemiluminescence detection on Hyperfilm (Thermo Fisher Scientific, Waltham, MA).

\section{Mouse Immunization and Subsequent Infection With C. difficile Spores or Challenge With TcdA/TcdB}

Female $\mathrm{C} 57 \mathrm{BL} / 6$ mice were housed under the same conditions. Mice $(n=20)$ were immunized three times at 14 -days intervals via i.m. route with $10 \mu \mathrm{g}$ of Tcd169FI or Tcd169 in phosphatebuffered saline (PBS) along with alum as an adjuvant for each injection (34). Control mice $(n=20)$ only received PBS with alum. Sera were collected.

Fourteen days after the third immunization, immunized and control mice $(n=10)$ were given a mixture of five antibiotics including kanamycin $(0.4 \mathrm{mg} / \mathrm{ml})$, gentamycin $(0.035$ $\mathrm{mg} / \mathrm{ml})$, colistin $(850 \mathrm{U} / \mathrm{ml})$, metronidazole $(0.215 \mathrm{mg} / \mathrm{ml})$, and vancomycin $(0.045 \mathrm{mg} / \mathrm{ml})$ in the drinking water for 4 days. After 4 days of antibiotic treatment, all mice were given autoclaved water for 2 days, followed by a single dose of clindamycin 
$(10 \mathrm{mg} / \mathrm{kg}$ ) intraperitoneally (i.p.) 1 day before challenge with $10^{6}$ C. difficile UK1 (35) spores/mouse by gavage. During the antibiotic pretreatment, food, water, bedding, and cages were autoclaved. Animals were monitored daily for weight changes, diarrhea and survival, and moribund animals were euthanized. The fecal samples were collected on days $0,1,3$, and 5 postchallenge. Diarrhea was defined as wet tails, loosen or watery feces. The death included the numbers of mice died after infection and mice euthanized if weight loss was $>20 \%$.

The remaining 10 mice from Tcd169-/Tcd169Fl-immunized group or control group were i.p., challenged with lethal dosages of TcdA (200 ng/moue, $n=5$ for each protein group) or TcdB (100 ng/mouse, $n=5$ for each protein group), monitored for survival and disease symptoms for $80 \mathrm{~h}$.

\section{ELISA For Anti-toxin/sFlic IgG/lgA Titers}

ELISAs were performed as previously described (25). Briefly, costar 96-well ELISA plates were coated with $100 \mu \mathrm{l} /$ well of $\operatorname{TcdA}(0.5 \mu \mathrm{g} / \mathrm{ml}), \operatorname{TcdB}(0.5 \mu \mathrm{g} / \mathrm{ml})$, or sFliC $(0.5 \mu \mathrm{g} / \mathrm{ml})$ at $4^{\circ} \mathrm{C}$ overnight. Following washing of the unbound material, plates were blocked with $300 \mu \mathrm{l}$ of blocking buffer (PBS $+5 \%$ dry milk) at RT for $2 \mathrm{~h}$. After washing, $100 \mu \mathrm{l}$ of 10 -fold serially diluted sera or fecal samples were added into each well of the plates, and incubated for $1.5 \mathrm{~h}$ at RT. Following washing with PBS, $100 \mu \mathrm{l}$ of mouse IgG-HRP $(1: 3,000)$ or mouse IgA-HRP $(1: 3,000)$ were added to each well, and incubated for $30 \mathrm{~min}$ to $1 \mathrm{~h}$. Subsequent to a washing step with PBS, substrate TMB was added to allow color development at room temperature for 5-30 min. The reaction was stopped by addition of $\mathrm{H}_{2} \mathrm{SO}_{4}$ to each well, and the OD values at $450 \mathrm{~nm}$ were recorded by a spectrophotometer. Antitoxin/-FliC IgG or IgA titer of a given sample (serum or fecal samples from immunized mice) was defined as the dilution factor at which the $\mathrm{OD}_{450 \mathrm{~nm}}$ is greater than or equal to that of serum or fecal sample from non-immunized mice.

\section{Neutralizing Assay}

Mouse intestinal epithelial CT26 cells were used to assess in vitro neutralizing activities of serum samples. The neutralizing titer is defined as the maximum dilution of the samples that blocks cell rounding induced by toxin at a given concentration. This given concentration is four times the minimum dose of the toxin that causes all cells round after a $24 \mathrm{~h}$ exposure to the toxin, i.e., 1.6 and $0.04 \mathrm{ng} / \mathrm{ml}$ for TcdA and TcdB, respectively.

\section{Measurement of Antitoxin IgG Isotypes}

IgG1, IgG2a, IgG2b, IgG2c, and IgG3 anti-TcdA/B concentrations in the sera of Tcd169- or Tcd169Fl-immunized mice were determined by ELISA using biotinylated anti-mouse IgG isotype antibodies.

\section{Determination of Anti-glucosyltransferase Activity of TcdB Imposed by Sera From Tcd169- or Tcd169FI-Immunized Mice}

Glucosyltransferase (GT) activity of TcdB was measured by its ability to glucosylate Rho GTPase Racl in cell lysates (36). CT26 cell pellets were resuspended in a reaction buffer $(50 \mathrm{mM}$ HEPES, pH 7.5, $100 \mathrm{mM} \mathrm{KCl,} 1 \mathrm{mM} \mathrm{MnCl}_{2}$, and $2 \mathrm{mM} \mathrm{MgCl} 2$ ), and lysed by passing through a $30 \mathrm{G}$ needle for 40 times. After centrifugation $(16,700 \mathrm{~g}, 3 \mathrm{~min})$, the supernatant was used as a cytosolic fraction (protein concentration $2.5 \mathrm{mg} / \mathrm{ml}$ ). To perform the glucosylation assay, the cytosolic fraction was incubated with $\mathrm{TcdB}$ at $10 \mathrm{ng} / \mathrm{ml}$ (with or without serum, sera were diluted at $1: 200)$ at $37^{\circ} \mathrm{C}$ for $60 \mathrm{~min}$. The reaction was terminated by adding SDS-sample buffer, and samples were heated at $100^{\circ} \mathrm{C}$ for 5 min before loading on a 12\% SDS-PAGE gel. An antibody that specifically recognizes the non-glucosylated form of Rac1 (clone 102, BD Bioscience), anti- $\beta$-actin (clone AC-40, Sigma), and HRP-conjugated anti-mouse-IgG (Amersham Biosciences) were used for Western blotting.

\section{In vitro TcdB Autoproteolysis Assay}

The autoproteolysis assays were performed in $25 \mu \mathrm{l}$ of $20 \mathrm{mM}$ Tris- $\mathrm{HCl} \mathrm{pH}$ 8.0, containing $0.2 \mu \mathrm{g}$ of $\mathrm{TcdB}$ (37), and the indicated concentration of Inositol hexakisphosphate (InsP6) to induce cleavage. Unless otherwise indicated, the samples were incubated at $37^{\circ} \mathrm{C}$ for $1 \mathrm{~h}$, then boiled for $5 \mathrm{~min}$ in SDS sample buffer containing $\beta$-mercaptoethanol (BME) to halt the reaction. Samples were then separated by $8 \%$ SDS-PAGE, and the toxin fragments visualized by Coomassie blue staining. Preserum and serum of Tcd169- or Tcd169FI-immunized mice were diluted at 1:200 in the autoprocessing reactions.

\section{Binding of Toxins to CT26 Cells}

CT26 cells were exposed to the TcdA or TcdB at $10 \mu \mathrm{g} / \mathrm{ml}$ with or without preserum or serum from Tcd169- or Tcd169Flimmunized mice at $4^{\circ} \mathrm{C}$, for $30 \mathrm{~min}$, after being washed three times, cells were collected for Western Blot analysis using antiTcdA or anti-TcdB antibodies. Preserum and serum of Tcd169- or mTcd169FI-immunized mice were diluted at 1:200 in the binding reaction system.

\section{Quantification of C. difficile Spores in Mouse Feces}

Fecal samples were collected on days $0,1,3$, and 5 postinfection. Fifty milligrams of feces were dissolved with $500 \mu \mathrm{l}$ sterile water for $16 \mathrm{~h}$ at $4^{\circ} \mathrm{C}$, and then treated with $500 \mu \mathrm{l}$ of purified ethanol (Sigma-Aldrich) for $60 \mathrm{~min}$ at room temperature to kill vegetative cells. Samples were vortexed, serially diluted, and plated onto selective medium (TCCA) supplemented with taurocholate $(0.1 \% \mathrm{w} / \mathrm{v})$, cefoxitin $(16 \mu \mathrm{g} / \mathrm{mL})$, and L-cycloserine $(250 \mu \mathrm{g} / \mathrm{mL})$. The plates were incubated anaerobically at $37^{\circ} \mathrm{C}$ for $48 \mathrm{~h}$, colonies counted, and results expressed as the CFU/gram of feces.

\section{Quantitation of C. difficile Toxins in Mouse Feces}

After challenges with $C$. difficile spores, feces were collected, and dissolved in sterile PBS $(0.1 \mathrm{~g} / \mathrm{ml})$ containing protease inhibitor cocktail, and the supernatants were collected after centrifugation and stored at $-80^{\circ} \mathrm{C}$. TcdA/TcdB concentrations in fecal samples were determined by ELISA. Briefly, 96-well microplates were coated with $100 \mu \mathrm{l}$ of anti-TcdA $(1 \mu \mathrm{g} / \mathrm{ml})$ or anti-TcdB antibody $(1 \mu \mathrm{g} / \mathrm{ml})$ overnight in $\mathrm{PBS}$ at $4^{\circ} \mathrm{C}$. On the next day, each well was blocked with $300 \mu l$ of 
blocking buffer (PBS $+5 \%$ dry milk) at RT for $2 \mathrm{~h}$. Next, standards and samples were added to each well $(100 \mu \mathrm{l})$ in duplicate, and incubated for $90 \mathrm{~min}$ at $25^{\circ} \mathrm{C}$. After another set of washes, HRP-chicken anti-TcdA or anti-TcdB (1:5,000 dilution in PBS, Gallus Immunotech, Shirley, MA) was added to wells for $30 \mathrm{~min}$ at RT. A final set of three washes preceded the addition of the TMB Microwell Peroxidase Substrate for $20 \mathrm{~min}$ at RT in the dark. The reaction was stopped with $2 \mathrm{~N}$ $\mathrm{H}_{2} \mathrm{SO}_{4}$, and the absorbance was measured using a plate reader at $450 \mathrm{~nm}$.

\section{mTLR5 Activation Assay}

The ability of FliC and Tcd169FI to activate TLR5 was determined using a reporter assay system as previously described $(38,39)$.
In brief, HEK-Blue mTLR5 cells (Invivogen, San Diego, CA) were plated in HEK-Detection Medium at a concentration of $\sim 25,000$ cells per well (96-well plate) in the presence of sFliC, Tcd169FI, Tcd169, or $\mathrm{H}_{2} \mathrm{O}$. After incubation overnight at $37^{\circ} \mathrm{C}$, absorbance at $620 \mathrm{~nm}$ was measured correlating to TLR5 activation.

\section{Statistical Analysis}

Data were analyzed by Kaplan-Meier survival analysis with a $\log$ rank test of significance, by analysis of variance (ANOVA), and by one-way or two-way ANOVA followed with Bonferroni posttests using the Prism statistical software program. Results are expressed as means \pm standard errors of means. Differences were considered statistically significant if $p<0.05$.

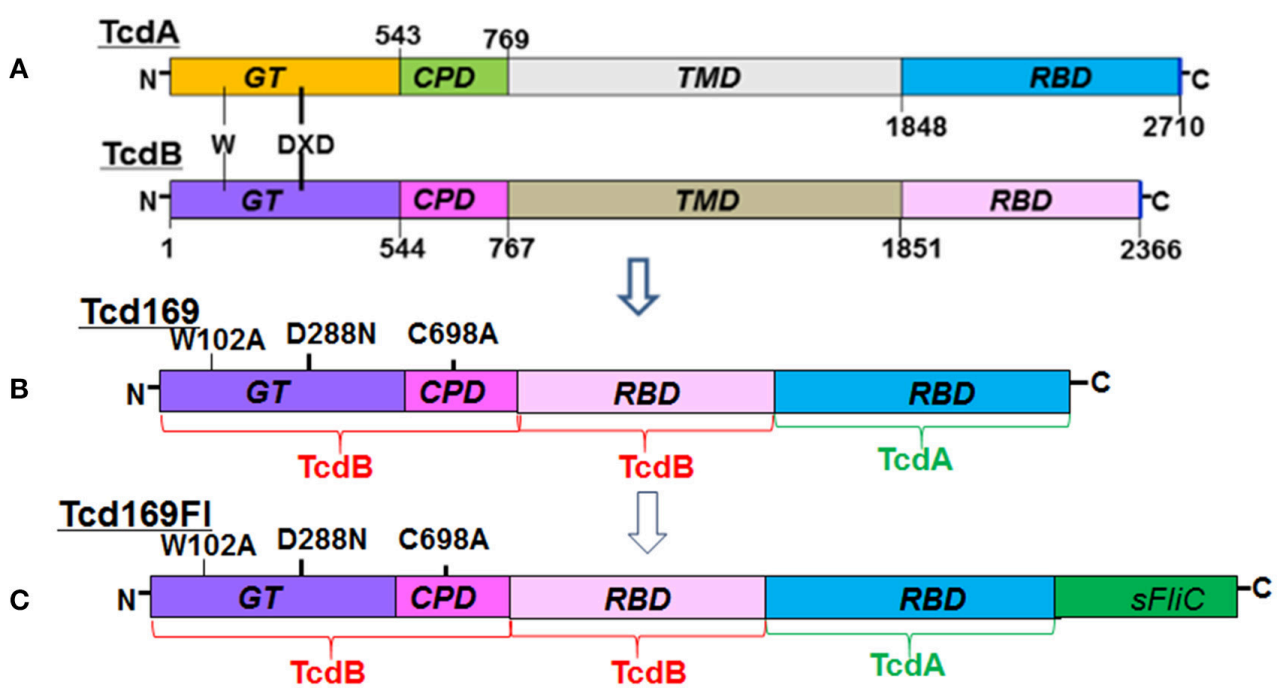

FIGURE 1 | Domains of TcdA and TcdB and construction of Tcd169 and Tcd169FI. (A) Both toxins share similar domains, including the glucosyltransferase domain (GT), the cysteine proteinase domain (CPD), the translocation domain (TMD), and the receptor binding domain (RBD). The DXD (D286-x-D288) motif and a conserved tryptophan in the GT are involved in the enzymatic activity. (B) Tcd169 was constructed by fusing the GT, CPD, and RBD of TcdB with the RBD of TcdA. Two point mutations were made in the GT of TcdB and one point mutation was made in the CPD of TcdB; these mutations essentially eliminate the toxicity of Tcd169 and Tcd169FI. (C) Tcd169FI was constructed by fusing the Salmonella typhimurium flagellin (sFliC) with Tcd169.

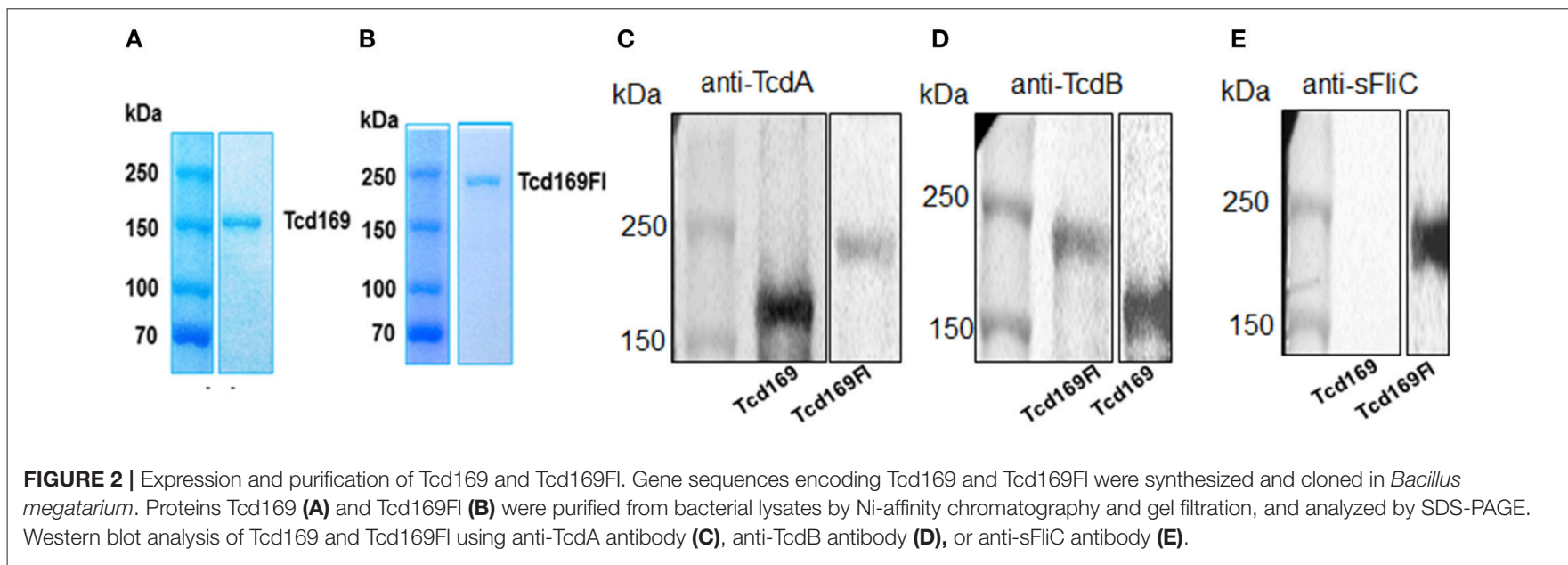




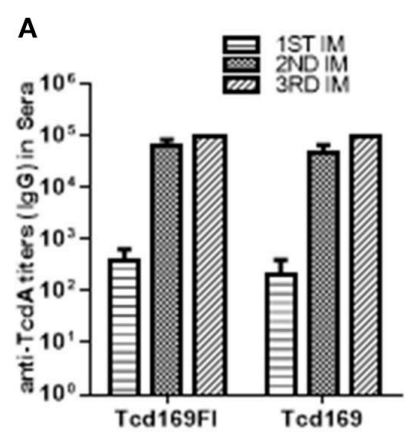

D

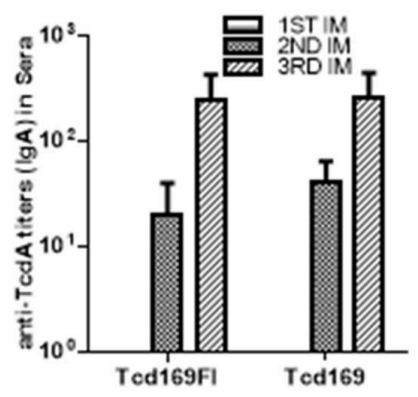

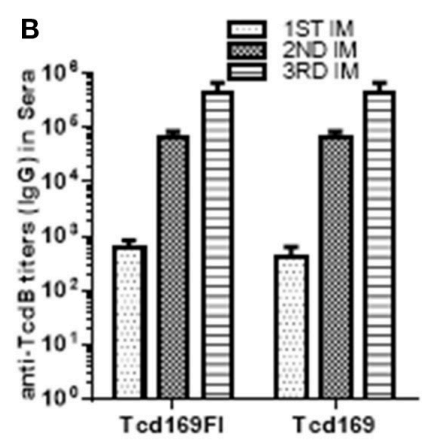

E

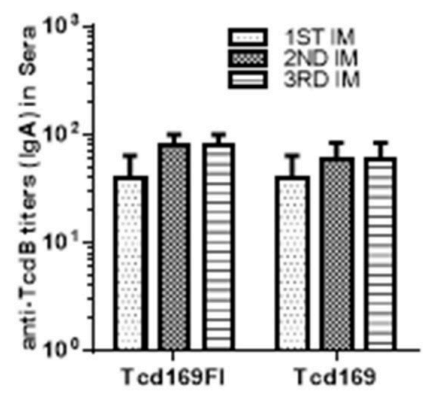

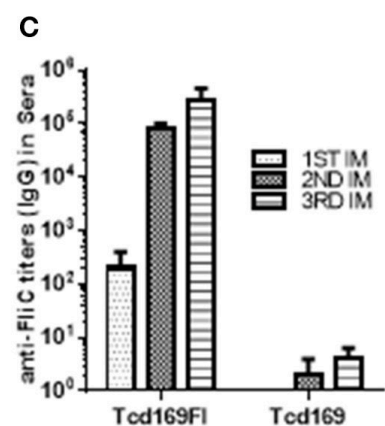

$\mathbf{F}$

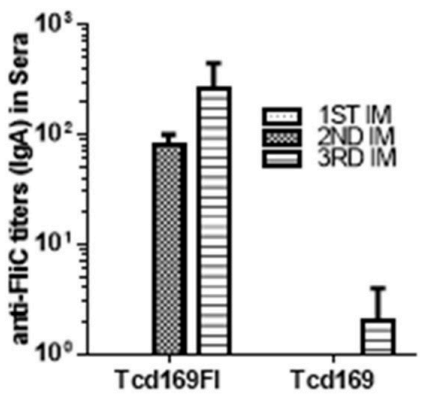

FIGURE 3 | Tcd169 and Tcd169FI immunizations via intramuscular (i.m.) route induce similar levels of anti-TcdA/anti-TcdB antibodies in sera. Groups of C57BL/6 mice $(n=10)$ were immunized three times at 14-days intervals via i.m. route with $10 \mu \mathrm{g}$ of Tcd169 or Tcd169FI in combination of alum as an adjuvant. Sera were collected, and anti-TcdA (A), anti-TcdB (B), or anti-sFliC (C) lgG titers measured by standard ELISA. Anti-TcdA (D), anti-TcdB (E), or anti-sFliC (F) IgA titers were also measured by standard ELISA. Results are given as mean \pm SD.

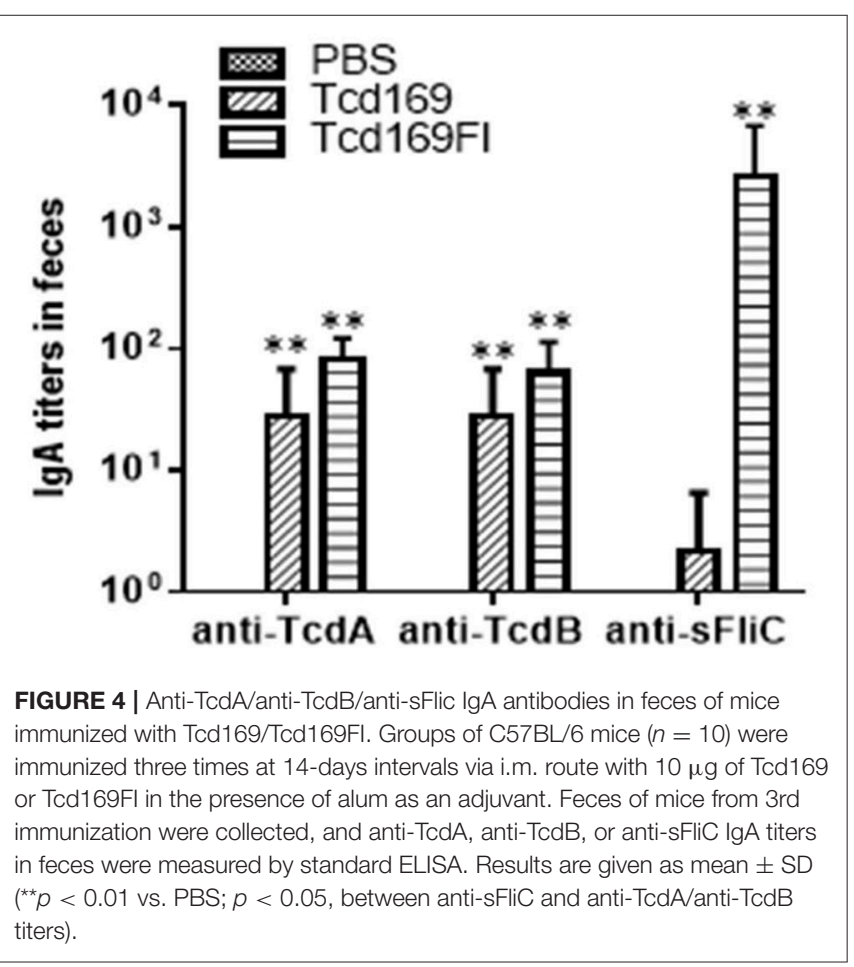

\section{RESULTS}

\section{Construction and Purification of Tcd169 and Tcd169FI}

The RBDs of TcdB and TcdA are highly immunogenic (20, $22,23)$. In our previous study $(25,26)$, and consistent with others $(27,28)$, we showed that GTD of TcdB was able to elicit a protective antibody response. We (25) and others (29) also found that CPD could play important roles in maintaining the native structure or epitope conformation of GTD. To enhance the immunogenicity of the immunogen, we fused GT, CPD, and RBD of TcdB and RBD of TcdA, resulting in Tcd169 (Figure 1). sFliC is a known potent adjuvant and protects mice from death during CDI by delaying C. difficile growth in the gut (30). Therefore, we fused Tcd169 with sFliC, resulting in protein Tcd169FI. The DXD (D286-x-D288) motif and a conserved tryptophan in the GT are involved in the enzymatic activity (40). The cysteine at the position 698 is a critical amino acid mediating CPD activity $(40,41)$. To ensure that Tcd169 and Tcd169FI were atoxic, point mutations were made in the GT (W102A, D288N) and CPD (C698A) of Tcd169 and mTcd169FI (Figure 1). Recombinant Tcd169 or Tcd169Fl with a 6xHistag was expressed in Bacillus megaterium, and purified by $\mathrm{Ni}$ affinity chromatography followed by ion exchange purification. 


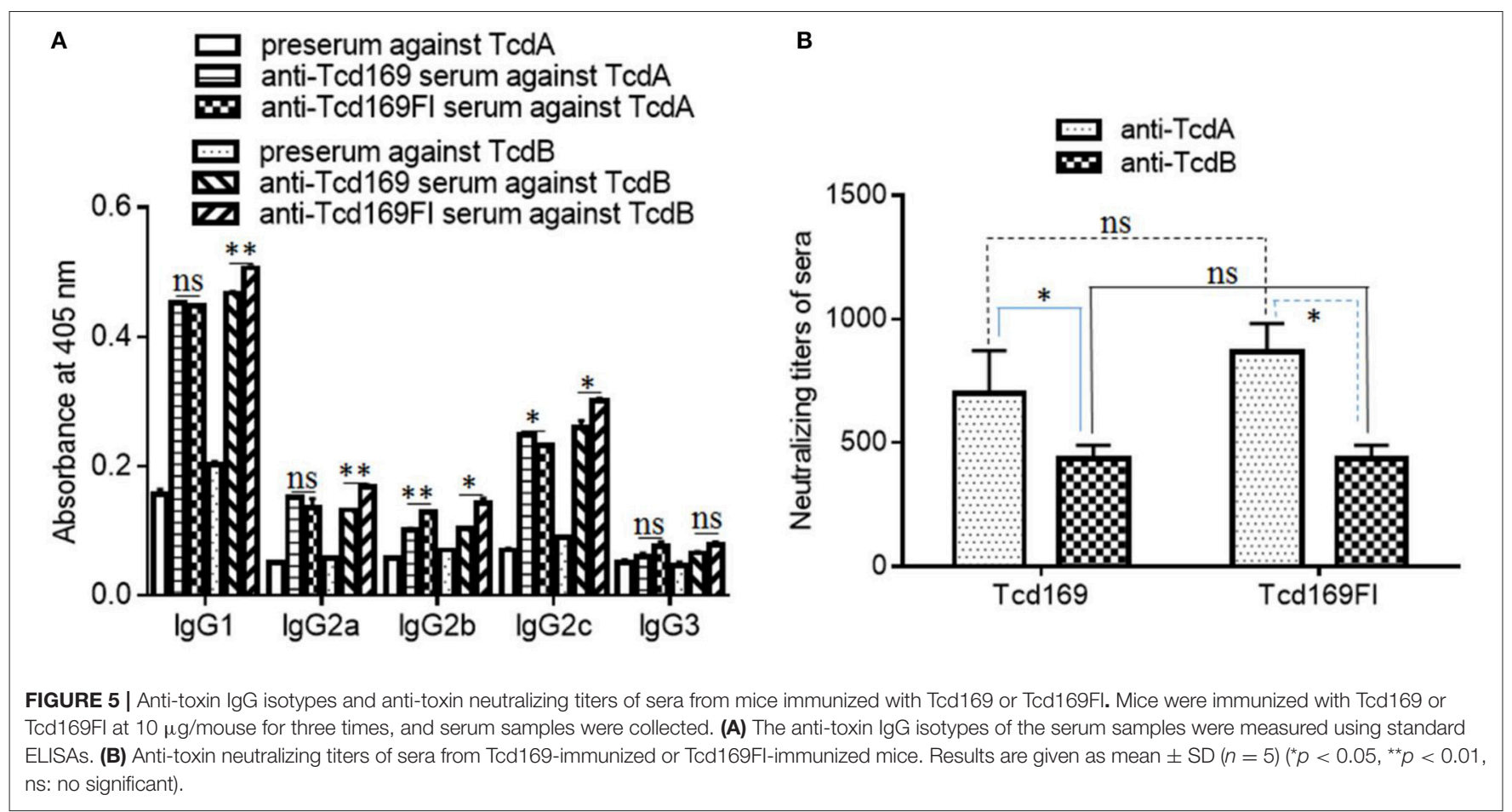

The purification process yielded a highly pure product of about $169 \mathrm{kDa}($ Tcd169, Figure 2A) or $211 \mathrm{kDa}$ (Tcd169FI, Figure 2B). Western blot analysis using specific antibodies against TcdA, $\mathrm{TcdB}$, or sFliC verified the presence of TcdA (Figure 2C), TcdB (Figure 2D), or sFliC (Figure 2E) fragments in Tcd169 or mTcd169Fl.

\section{Immunizations of Mice With Tcd169 or Tcd169FI Induce Potent IgG Antibody Responses Against TcdA/TcdB/sFlic, and Protect Mice Against Systemic Toxin Challenge}

Immunization of mice with $10 \mu \mathrm{g}$ Tcd169 or Tcd169Fl in combination with alum as an adjuvant via i.m. route induced similar levels of $\operatorname{IgG}$ and $\operatorname{IgA}$ antibody responses in sera to both toxins (Figures 3A,B,D,E). In addition, Tcd169Fl was also able to induce anti-sFliC IgG/IgA antibody responses in sera (Figures 3C,F). Significant and strong anti-TcdA, anti-TcdB or anti-sFlic IgG responses were induced in the first or second immunizations. Anti-TcdA/-TcdB/-sFlic IgA antibodies in feces of mice immunized with Tcd169/Tcd169FI were also detected (Figure 4). Interestingly, Tcd169Fl was able to induce much stronger anti-sFlic IgA responses than anti-TcdA/anti-TcdB IgA responses $(p<0.05)$.

In mice, IgG1 antibody is associated with Th2-like response, and IgG2a, IgG2b, IgG2c, and IgG3 antibodies are associated with Th1-like response $(42,43)$. Each IgG subclass can participate in the remove of the encapsulated pathogen by distinguished mechanisms. IgG2a and IgG2b show strongest binding to Fc receptors (44) and together with IgG3 fix complement better than IgG1 does; both IgG3 and IgG1 can cooperatively bind to bacteria. Therefore, an immune response with a broad subclass distribution would be useful against encapsulated pathogen. To determine the nature of immune responses (i.e., Th1 or Th2) elicited by Tcd169 or Tcd169Fl immunization, we measured isotypes of anti-TcdA/anti-TcdB IgGs. As shown in Figure 5A, at a dilution of $1 \times 10^{3}$, both anti-Tcd169 and anti-Tcd169Fl sera showed high levels of IgG1 and IgG2c subclass antibodies and significant amounts of IgG2c, IgG2a, and IgG2b, indicating that Tcd169 and Tcd169Fl immunizations can induce both Th1 and Th2 responses with the latter one being stronger. It was reported that Salmonella typhimurium flagerlin C (sFliC) has a potent adjuvant property and induces a Th2 response (45). Interestingly, we found that inclusion of sFliC in the Tcd169Fl induced significantly more anti-TcdB IgG subclass antibodies (IgG1, IgG2a, IgG2b, IgG2c) than Tcd169 did (Figure 5A); however, Tcd169Fl did not induce more anti-TcdA IgG subclass antibodies except IgG2b when compared with Tcd169 (Figure 5A).

The ultimate goal of vaccination targeting TcdA/TcdB is to illicit not only high-level anti-TcdA/TcdB antibodies but also potent toxin-neutralizers. Previously, we reported that not all anti-toxin antibodies are toxin-neutralizers, instead some of them are toxin-enhancers (46). Therefore, we also determined the in vitro toxin-neutralizing activities of anti-Tcd169 and antiTcd169Fl sera. As shown in Figure 5B, both Tcd169 and Tcd169Fl immunizations induced potent neutralizing antibodies against both TcdA and TcdB, with anti-TcdA neutralizing antibody titers being significantly higher than anti-TcdB neutralizing antibody titer in both anti-Tcd169 and anti-Tcd169Fl sera. However, it seemed that Tcd169 and Tcd169Fl induced comparable levels of anti-TcdA and anti-TcdB neutralizing antibodies. 


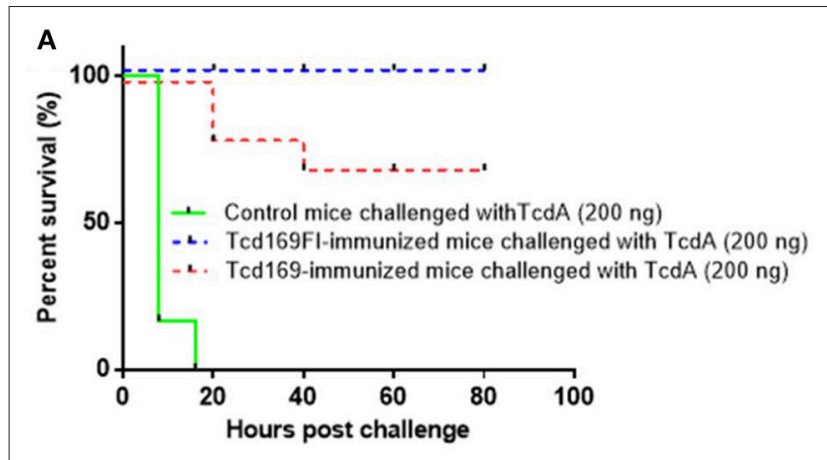

B

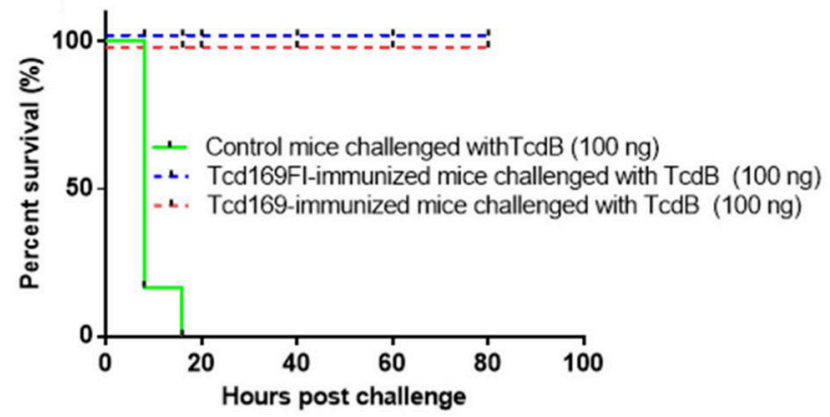

FIGURE 6 | Tcd169/Tcd169FI immunization protects mice against systemic toxin challenge. Fourteen days after third immunization, Tcd169- or Tcd169FIimmunized group or control group $(n=5)$ were i.p., challenged with lethal dosage of TcdA (200 ng/mouse) (A) or TcdB (100 ng/mouse) (B), and monitored for survival and disease symptoms for $80 \mathrm{~h}$. Kaplan-Meier survival plots of different groups of mice were shown $[P=0.0779$ between Tcd169and Tcd169Fl-immunized groups in (A)].

To assess the in vivo antitoxin neutralizing activities induced by Tcd169 or Tcd169 immunizations. After three immunizations with $10 \mu \mathrm{g}$ of Tcd169 or Tcd169Fl with alum as an adjuvant, immunized mouse groups $(n=5)$ and control no-immunized mouse groups $(n=5)$ were challenged with lethal doses of TcdA (200 ng/mouse) or TcdB (100 ng/mouse), and mice were monitored for $80 \mathrm{~h}$ for survival and other disease symptoms. Immunization of mice with Tcd169 or Tcd169Fl provided full protection against systemic challenge of lethal dose of TcdB (100 ng) (Figure 6). Tcd169Fl immunization also provided mice full protection against TcdA (200 ng) challenge, while Tcd169 immunization only provided partial but significant protection against TcdA challenge, indicating sFliC portion of the Tcd169Fl may enhance the neutralizing activity of anti-TcdA antibodies in vivo.

\section{Glucosyltransferase and Cysteine Proteinase Activities of TcdB Are Inhibited by Anti-Tcd169 or Anti-Tcd169FI Serum}

Since both Tcd169 and Tcd169Fl contain GTD and CPD domains of TcdB, we assessed whether anti-Tcd169 and anti-Tcd169Fl sera can inhibit GT and cysteine activities of TcdB. To this end, we first determined whether anti-Tcd169 and anti-Tcd169Fl sera
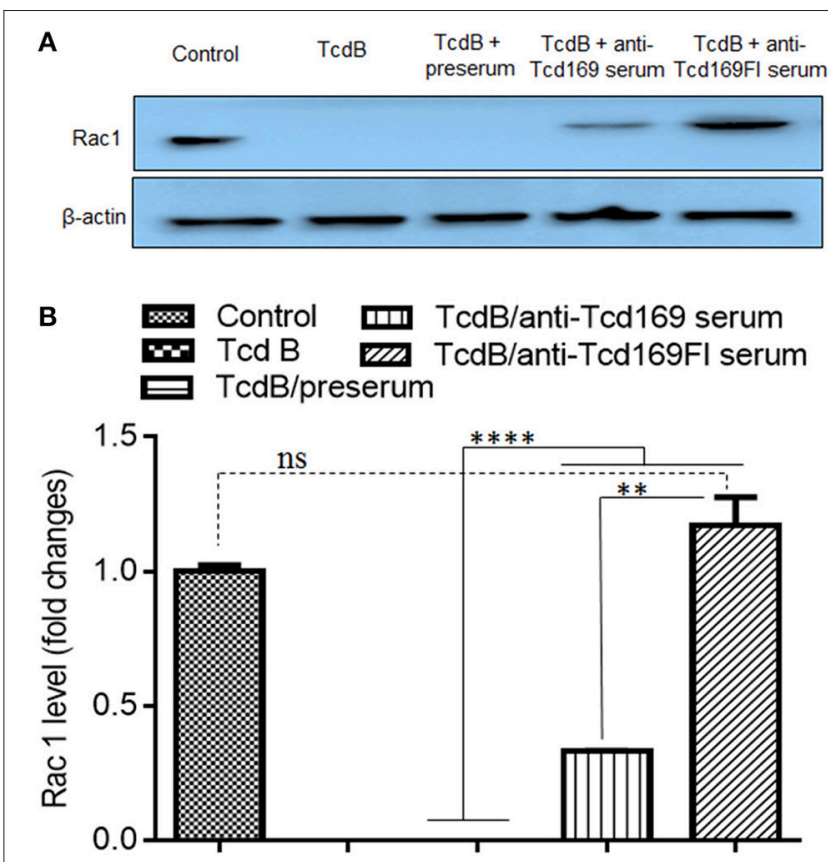

FIGURE 7 | Glucosyltransferase activity of TcdB is blocked by anti-Tcd169 or anti-Tcd169FI serum. (A) CT26 cells were lysed, and the cytosolic fraction was exposed to TcdB $(10 \mathrm{ng} / \mathrm{ml})$ with or without serum for $1 \mathrm{~h}$ followed by Western Blot analysis using a monoclonal antibody that only recognizes non-glucosylated Rac1. $\beta$-actin was used as an equal loading control. (B) Quantitation of Rac1 levels in (A) ${ }^{* *} p<0.01,{ }^{* * *} p<0.0001$, ns: no significant).

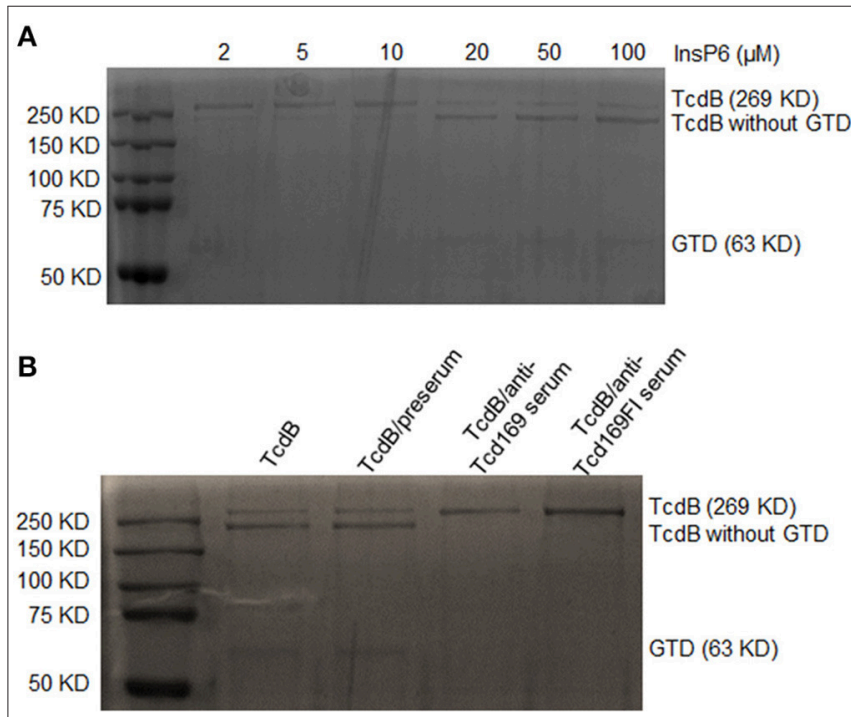

FIGURE 8 | In vitro autocleavage of TcdB mediated by cysteine proteinase domain (CPD) is blocked by anti-Tcd169 or anti-Tcd169FI serum.

(A) SDS-PAGE of TcdB autocleavage in the presence of InsP6 (2-100 $\mu \mathrm{M})$. (B) The activation of CPD-mediated TcdB autocleavage by InsP6 $(20 \mu \mathrm{M})$ was blocked by anti-Tcd169 or anti-Tcd169FI serum. Full-length TcdB (269 KD) and TcdB without GTD (544-2366 aa), glucosyltransferase domain (GTD, 1-543 aa, 63KD) are indicated. 

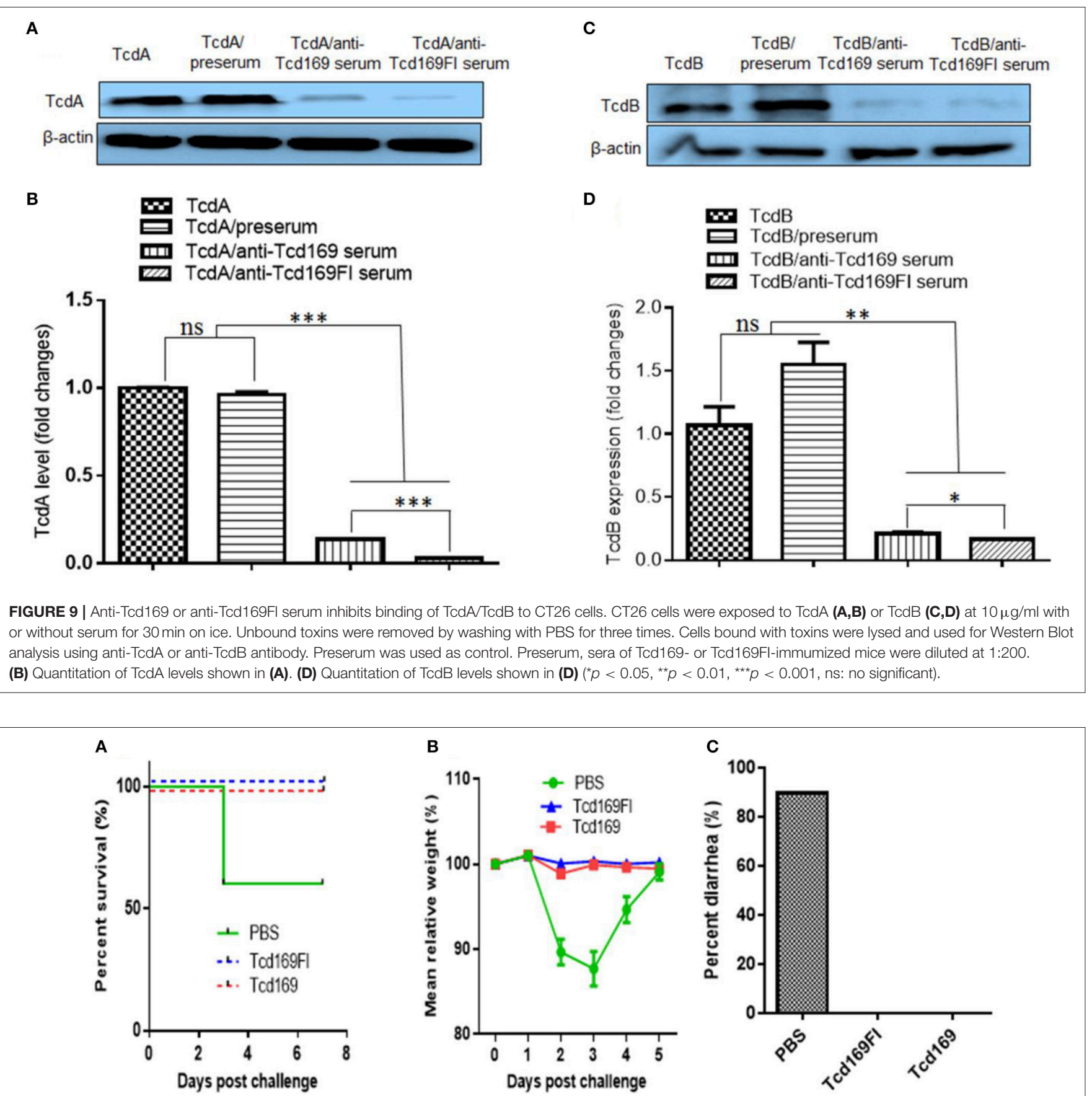

FIGURE 10 | Tcd169 or Tcd169FI immunization via i.m. route provides mice full protection against infection with C. difficile strain UK1. Mice $(n=10)$ were challenged with C. difficile UK1 spores (106/mouse) 14 days after the third immunization with Tcd169, Tcd169FI, or PBS. Kaplan-Meier survival plots $(P=0.002754$ between PBS-immunized and the 2 immunized groups) (A), mean relative weight of all surviving mice (up to the day of death) (B), and frequency of diarrhea (C) of different groups were illustrated. Data are presented as mean $\pm \operatorname{SD}(n=10)$.

can inhibit TcdB-mediated glucosylation/inactivation of Rac1 in CT26 cell lysates by Western blot analysis using an antibody only recognizing non-glucosylated Rac1. As shown in Figure 7, both anti-Tcd169 or anti-Tcd169Fl sera at 1:200 dilution significantly inhibited TcdB (10 ng/ml)-mediated glucosylation/inactivation of Rac1 in CT26 cell lysates. Interestingly, anti-Tcd169Fl serum was significantly more effective than anti-Tcd169 serum in blocking GT activity of $\mathrm{TcdB}$ (Figure 7), indicating that sFlic portion of Tcd169Fl can significant enhance anti-GTD responses. 

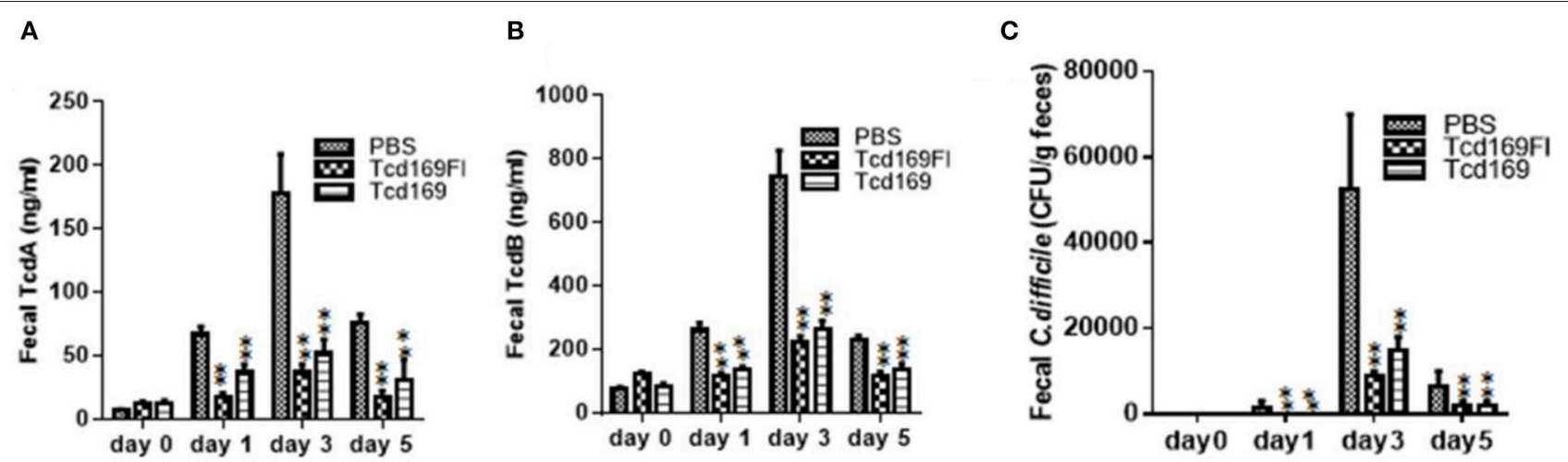

FIGURE 11 | Immunizations of mice with Tcd169 or Tcd169FI decrease numbers of $C$. difficile spores and toxin levels in the feces after infection with C. difficile spores. C. difficile-challenged mice were monitored for fecal TcdA (A) and TcdB (B) levels or $C$. difficile spore shedding (C). Data are given as mean $\pm \mathrm{SD}\left({ }^{\star \star} P<0.01\right.$ vs. PBS; $P<0.05$ in (A) day 1 and in (C) day 3 between Tcd169 and Tcd 169FI groups, others have no difference between Tcd169 and Tcd $169 \mathrm{FI}$ groups, $P>0.1)$.

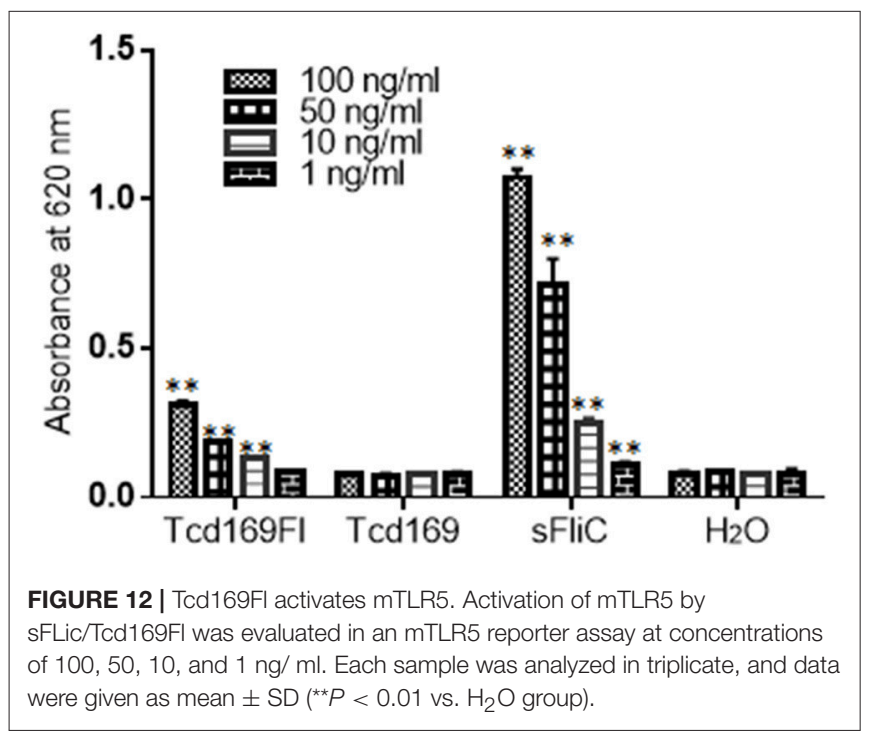

We then determined whether anti-Tcd169 and anti-Tcd169Fl sera can inhibit CPD-mediated autocleavage of TcdB. TcdB of 0.2 $\mu \mathrm{g}$ were incubated with InsP6, ranging in concentrations from 2 to $100 \mu \mathrm{M}$ at $37^{\circ} \mathrm{C}$ for $1 \mathrm{~h}$, and the reactions were stopped and resolved by SDS-PAGE. As shown in Figure 8A, InsP6 induced a dose-dependent autocleavage of $\mathrm{TcdB}$. To examine if the anti-Tcd169 and Tcd169FI sera can inhibit the TcdB autoprocessing, sera at 1:200 dilution were added to the reaction system containing $20 \mu \mathrm{M}$ of InsP6. As shown in Figure 8B, the TcdB autoprocessing was completely blocked by anti-Tcd169 or anti-Tcd169FI serum.

\section{Anti-Tcd169 or Anti-Tcd169FI Serum Inhibits the Binding of TcdA/TcdB to CT26 Cells}

Since both Tcd169 and Tcd169Fl contain RBD domains of TcdB and TcdA, we examined whether the binding of TcdA or TcdB to the CT26 cells is affected by the anti-Tcd169 or Tcd169Fl serum.
CT26 cells were exposed to the TcdA or TcdB at $10 \mu \mathrm{g} / \mathrm{ml}$ with or without preserum or anti-Tcd169 or anti-Tcd169Fl serum at $4{ }^{\circ} \mathrm{C}$, for $30 \mathrm{~min}$, after being washed three times, cells were collected for Western Blot analysis using anti-TcdA or anti-TcdB antibodies. As shown in Figure 9, both anti-Tcd169 and anti-Tcd169Fl sera at a dilution of 1:200 significantly inhibited bindings of both TcdA and TcdB to CT26 cells, while the anti-Tcd169Fl serum was significantly more effective in blocking the bindings of TcdA and TcdB to CT26 cells, suggesting that sFlic portion of Tcd169Fl can significant enhance anti-RBD responses.

\section{Tcd169/Tcd169FI Vaccinations Protect Mice Against Infection With an Epidemic C. difficile Strain}

We further evaluated the protection efficacy of Tcd169, Tcd169Fl in a mouse model of CDI. After three immunizations via i.m., mice were challenged with $10^{6}$ spores of $C$. difficile UK1. Approximately 40\% PBS-immunized mice died or became moribund and were euthanized by day 3 post-infection (Figure 10A). In contrast, Tcd169, Tcd169FI-immunized mice showed no appreciable signs of disease (Figure 10). Nine of ten mice in PBS-immunized mice developed weight loss (Figure 10B) and diarrhea (Figure 10C).

\section{Immunizations of Mice With Tcd169 or Tcd169FI Decrease C. difficile Spores and Toxin Levels in the Feces After Infection}

Immunization of mice with Tcd169 and Tcd169Fl significantly decreased TcdA (Figure 11A) and TcdB (Figure 11B) concentrations, and the spore count (Figure 11C) in feces, in comparison with PBS-immunized group. In addition, immunization of mice with Tcd169Fl significantly decreased spore count in feces, in comparison with Tcd169-immunized mice (Figure 11C), indicating that sFliC portion of the Tcd169Fl may stimulate immune responses targeting $C$. difficile colonization. In fact, Tcd169Fl was able to induce much stronger 
anti-sFlic IgA responses than anti-TcdA/anti-TcdB IgA responses (Figure 4).

\section{Tcd169FI Stimulates TLR5 Activation}

Toll-like receptor 5 (TLR5) is known to recognize bacterial flagellin from invading mobile bacteria (47). By using a murine model, Jarchum et al. (48) showed that TLR5 stimulation protects mice from acute $C$. difficile colitis. To investigate whether Tcd169Fl can activate TLR5, we performed the TLR5 reporter assay. As shown in Figure 12, Tcd169Fl still activated TLR5 at concentrations of 100,50 , and $10 \mathrm{ng} / \mathrm{ml}$, while Tcd169 did not.

\section{DISCUSSION}

We generated a new chimeric protein, Tcd169, by fusing GT, CPD, and RBD of TcdB and RBD of TcdA. We further fused Tcd169 with sFliC, generating Tcd169FI. Immunization of mice with Tcd169 or Tcd169Fl induced protective immunity against $\mathrm{Tcd} A / \mathrm{TcdB}$ challenge through intraperitoneal injection, also provided mice full protection against infection with a hyper-virulent $C$. difficile strain (BI/NAP1/027). Our results showed that immunizations with Tcd169 or Tcd169Fl could: (1) induce both Th1 and Th2 responses while at different extent (Figure 5); and (2) induce protective immune responses against all toxin domains included in the two fusion proteins (Figures 7-9). Interestingly, our data suggest that inclusion of sFlic in the fusion protein (Tcd169Fl) can significantly enhance its protective immunity, when compared with Tcd169, by (1) inducing significantly more anti-TcdB IgGs and anti-TcdA IgG2b (Figure 5A); (2) inducing significantly more anti-GTD of TcdB (Figure 7) and anti-RBD of TcdB/TcdA (Figure 9) antibodies; (3) inducing more anti-TcdA neutralizing antibodies in vivo (Figure 6); (4) reducing C. difficile dissemination and TcdA/TcdB levels in feces from Tcd169Fl-immunized mice infected C. difficile in comparison with Tcd169-immunized mice (Figure 11); and (5) stimulating TLR5 activation, though at a reduced level in comparison with sFlic stimulation alone (Figure 12).

Overall, our results are in agreement with previous reports by other groups showing that $\mathrm{sFliC}$ is able to enhance the immunogenicity of immunogens $(30,49)$ and that administration of purified Salmonella-derived flagellin, a Toll-like receptor 5 (TLR5) agonist, protects mice from $C$. difficile colitis by delaying C. difficile growth and toxin production (48). There are a few slight data discrepancies, i.e., we did not find significant differences in anti-TcdA/TcdA IgG titers (Figure 3) and in

\section{REFERENCES}

1. Leffler DA, Lamont JT. Clostridium difficile infection. N Eng J Med. (2015) 373:287-8. doi: 10.1056/NEJMra1403772

2. Cloud J, Kelly CP. Update on Clostridium difficile associated disease. Curr Opin Gastroenterol. (2007) 23:4-9. doi: 10.1097/MOG.0b013e3280 $1184 \mathrm{ac}$

3. Kelly CP, LaMont JT. Clostridium difficile - more difficult than ever. $N$ Eng J Med. (2008) 359:1932-40. doi: 10.1056/NEJMra0707500 vitro anti-TcdA/TcdB neutralizing titers (Figure 4) between antiTcd169 and anti-Tcd169Fl sera as observed in other experiments, which might be due to the sensitivities of the methods used. In addition, we observed sFliC-mediated enhanced in vivo antiTcdA, but not anti-TcdB, neutralizing activity (Figure 6). The sFliC-mediated enhancement of anti-TcdB neutralizing activity might be covered by the TcdB dosage effect.

We included C-termial regions of TcdA (aa 1848-2710) and TcdB (aa 1851-2366) in two fusion proteins Tcd169 and Tcd169Fl. Historically, these regions are called combined repetitive oligopeptides (CROP), and were considered RBD for TcdA and $\operatorname{TcdB}(50,51)$. Recently, two binding sites were postulated within the newly defined RBD of TcdB. TcdB region aa $1372-1493$ is bound by PVRL3 and TcdB region aa 15011830 by FZD receptor proteins, respectively, whereas $\mathrm{TcdB}$ CROP region (1851-2366) is bound by CSPG4 $(52,53)$. The recpetor binding regions of TcdA and corresponding receptors are less clear so far. It was reported that TcdA could interact with different surface carbohydrate structures and with two proteins (sucrase-isomaltase and glycoprotein gp96) (54). Our data showed that anti-Tcd169 or anti-Tcd169 serum could dramatically reduced and dimished bindings of both TcdA and TcdB to CT26 cells, indicating that CROP regions of $\mathrm{Tcd} A / \mathrm{TcdB}$ are still the major receptor binding sites with other reported/postulated binding sites as adjunctive niches for additional recepor bindings.

In the future, we will evaluate the effects of immunization dosages on antibody responses, and further evaluate the protecive efficay of Tcd169 and Tcd169Fl in hamster model of CDI.

\section{AUTHOR CONTRIBUTIONS}

$\mathrm{XS}$ designed the project and participated in data analysis. SW, YW, and YC performed experiments. SW, YW, XS, and CK participated in data analysis and wrote the manuscripts. All authors read and approved the final manuscript.

\section{ACKNOWLEDGMENTS}

This work was supported in part by National Institutes of Health grants (K01-DK092352, R21-AI113470, R03-DK112004, R01-AI132711) to XS and (R01 AI116596 and U19 AI 109776) to $\mathrm{CK}$.
4. Rupnik M, Wilcox MH, Gerding DN. Clostridium difficile infection: new developments in epidemiology and pathogenesis. Nat Rev Microbiol. (2009) 7:526-36. doi: 10.1038/nrmicro2164

5. Kuehne SA, Cartman ST, Heap JT, Kelly ML, Cockayne A, Minton NP. The role of toxin A and toxin B in Clostridium difficile infection. Nature (2010) 467:711-3. doi: 10.1038/nature09397

6. Magill SS, Edwards JS, Bamberg W, Beldavs ZG, Dumyati G, Kainer MA, et al. Multistate point- prevalence survey of health care- associated infections. $N$ Eng J Med. (2014) 370:1198-208. doi: 10.1056/NEJMoa1306801 
7. Lessa FC, Winston LG, McDonald LC. emerging infections program c. difficile surveillance team. burden of Clostridium difficile infection in the United States. N Eng J Med. (2015) 372:825-34. doi: 10.1056/NEJMoa1408913

8. Zhang D, Prabhu VS, Marcella SW. Attributable healthcare resource utilization and costs for patients with primary and recurrent Clostridium difficile infection in the United States. Clin Infect Dis. (2018) 66:1326-32. doi: $10.1093 / \mathrm{cid} / \mathrm{cix} 1021$

9. Louie TJ, Miller MA, Mullane KM, Weiss K, Lentnek A, Golan Y, et al. Fidaxomicin versus vancomycin for Clostridium difficile infection. $N$ Eng J Med. (2011) 364:422-31. doi: 10.1056/NEJMoa0910812

10. Guery B, Menichetti F, Anttila VJ, Adomakoh N, Aguado JM, Bisnauthsing $\mathrm{K}$, et al. Extended-pulsed fidaxomicin versus vancomycin for Clostridium difficile infection in patients 60 years and older (EXTEND): a randomised, controlled, open-label, phase 3b/4 trial. Lancet Infect Dis. (2018) 18:296-307. doi: 10.1016/S1473-3099(17)30751-X

11. Nelson RL, Suda KJ, Evans CT. Antibiotic treatment for Clostridium difficile-associated diarrhoea in adults. Cochrane Database Syst Rev. (2017) 3:CD004610. doi: 10.1002/14651858.CD004610.pub5

12. Yang, GL, Zhou B, Wang J, He X, Sun X, Nie W, et al. Expression of recombinant Clostridium difficile toxin $\mathrm{A}$ and $\mathrm{B}$ in Bacillus megaterium. BMC Microbiol. (2008) 8:192. doi: 10.1186/1471-2180-8-192

13. Gough E, Shaikh H, Manges AR. Systematic review of intestinal microbiota transplantation (fecal bacteriotherapy) for recurrent Clostridium difficile infection. Clin Infect Dis. (2011) 53:994-1002. doi: 10.1093/cid/cir632

14. Khoruts A, Dicksved J, Jansson JK, Sadowsky MJ. Changes in the composition of the human fecal microbiome after bacteriotherapy for recurrent Clostridium difficile-associated diarrhea. J Clin Gastroenterol. (2010) 44:354-60. doi: 10.1097/MCG.0b013e3181c87e02

15. Senior K. Faecal transplantation for recurrent $C$ difficile diarrhoea. Lancet Infect Dis. 13:200-1. doi: 10.1016/S1473-3099(13)70052-5

16. Henderson M, Bragg A, Fahim G, Shah M, Hermes-DeSantis ER. A review of the safety and efficacy of vaccines as prophylaxis for Clostridium difficile infections. Vaccines (2017) 5:E25. doi: 10.3390/vaccines5030025

17. de Bruyn G, Saleh J, Workman D, Pollak R, Elinoff V, Fraser NJ, et al. Defining the optimal formulation and schedule of a candidate toxoid vaccine against Clostridium difficile infection: a randomized Phase 2 clinical trial. Vaccine (2016) 34:2170-8. doi: 10.1016/j.vaccine.2016.03.028

18. Sheldon E, Kitchin N, Peng Y, Eiden J, Gruber W, Johnson E, et al. A phase 1, placebo-controlled, randomized study of the safety, tolerability, and immunogenicity of a Clostridium difficile vaccine administered with or without aluminum hydroxide in healthy adults. Vaccine (2016) 34:2082-91. doi: 10.1016/j.vaccine.2016.03.010

19. Bezay N, Ayad A, Dubischar K, Firbas C, Hochreiter R, Kiermayr S, et al. Safety, immunogenicity and dose response of VLA84, a new vaccine candidate against Clostridium difficile, in healthy volunteers. Vaccine (2016) 34:2585-92. doi: 10.1016/j.vaccine.2016.03.098

20. Jank T, Aktories K. Structure and mode of action of clostridial glucosylating toxins: the ABCD model. Trends Microbiol. (2008) 16:222-9. doi: 10.1016/j.tim.2008.01.011

21. Permpoonpattana P, Hong HA, Phetcharaburanin J, Huang JM, Cook J, Fairweather NF, et al. Immunization with Bacillus Spores expressing toxin A peptide repeats protects against infection with Clostridium difficile strains producing toxins A and B. Infect Immun. (2011) 79:2295-302. doi: 10.1128/IAI.00130-11

22. Aktories K. Bacterial protein toxins that modify host regulatory GTPases. Nat Rev Microbiol. (2011) 9:487-98. doi: 10.1038/nrmicro2592

23. Tian JH, Glenn G, Flyer D, Zhou B, Liu Y, Sullivan E, et al. Clostridium difficile chimeric toxin receptor binding domain vaccine induced protection against different strains in active and passive challenge models. Vaccine (2017) 35:4079-87. doi: 10.1016/j.vaccine.2017.06.062

24. Tian JH, Fuhrmann SR, Kluepfel-Stahl S, Carman RJ, Ellingsworth L, Flyer DC, et al. A novel fusion protein containing the receptor binding domains of C. difficile toxin A and toxin B elicits protective immunity against lethal toxin and spore challenge in preclinical efficacy models. Vaccine (2012) 30:4249-58. doi: 10.1016/j.vaccine.2012.04.045

25. Wang YK, Yan YK, Kim HB, Ju X, Zhao S, Zhang K, et al. A chimeric protein comprising the glucosyltransferase and cysteine proteinase domains of toxin $\mathrm{B}$ and the receptor binding domain of toxin $\mathrm{A}$ induces protective immunity against Clostridium difficile infection in mice and hamsters. Hum Vaccin Immunother. (2015) 11:2215-22. doi: 10.1080/21645515.2015.1052352

26. Wang H, Sun X, Zhang Y, Li S, Chen K, Shi L, et al. A chimeric toxin vaccine protects against primary and recurrent Clostridium difficile infection. Infect Immun. (2012) 80:2678-88. doi: 10.1128/IAI.00215-12

27. Jin K, Wang S, Zhang C, Xiao Y, Lu S, Huang Z. Protective antibody responses against Clostridium difficile elicited by a DNA vaccine expressing the enzymatic domain of toxin B. Hum Vaccin Immunother. (2013) 9:63-73. doi: 10.4161/hv.22434

28. Leuzzi R, Spencer J, Buckley A, Brettoni C, Martinelli M, Tulli L, et al. Protective efficacy induced by recombinant Clostridium difficile toxin fragments. Infect Immun. (2013) 81:2851-60. doi: 10.1128/IAI.01341-12

29. Maynard-Smith M, Ahern H, McGlashan J, Nugent P, Ling R, Denton H, et al. Recombinant antigens based on toxins $\mathrm{A}$ and $\mathrm{B}$ of Clostridium difficile that evoke a potent toxin-neutralising immune response. Vaccine (2014) 32:700-5. doi: 10.1016/j.vaccine.2013.11.099

30. Ghose C, Verhagen JM, Chen X, Yu J, Huang Y, Chenesseau O, et al. Toll-like receptor 5-dependent immunogenicity and protective efficacy of a recombinant fusion protein vaccine containing the nontoxic domains of Clostridium difficile toxins A and B and Salmonella enterica Serovar Typhimurium flagellin in a mouse model of Clostridium difficile disease. Infect Immun. (2013) 81:2190-6. doi: 10.1128/IAI.01074-12

31. Bruxelle JF, Mizrahi A, Hoÿs S, Collignon A, Janoir C, Péchiné S, et al Clostridium difficile flagellin FIiC: evaluation as adjuvant and use in a mucosal vaccine against Clostridium difficile. PloS ONE (2017) 12:e0187212. doi: 10.1371/journal.pone.0187212

32. Perez J, Springthorpe VS, Sattar SA. Clospore: a liquid medium for producing high titers of semi-purified spores of Clostridium difficile. J AOAC Int. (2011) 94:618-26.

33. Sorg JA, Sonenshein AL. Inhibiting the initiation of Clostridium difficile spore germination using analogs of chenodeoxycholic acid, a bile acid. J Bacteriol. (2010) 192:4983-90. doi: 10.1128/JB.00610-10

34. Lee S, Picking WL, Tzipori S. The immune response of two microbial antigens delivered intradermally, sublingually, or the combination thereof. Microbes Infect. (2014) 16:796-803. doi: 10.1016/j.micinf.2014.07.013

35. Killgore G, Thompson A, Johnson S, Brazier J, Kuijper E, Pepin J, et al. Comparison of seven techniques for typing international epidemic strains of Clostridium difficile: restriction endonuclease analysis, pulsedfield gel electrophoresis, PCR-ribotyping, multilocus sequence typing, multilocus variable-number tandem-repeat analysis, amplified fragment length polymorphism, and surface layer protein A gene sequence typing. J Clin Microbiol. (2008) 46:431-7. doi: 10.1128/JCM.01484-07

36. Zhang Y, Shi L, Li S, Yang Z, Standley C, Yang Z, et al. A segment of 97 amino acids within the translocation domain of Clostridium difficile toxin B is essential for toxicity. PLoS ONE (2013) 8:e58634. doi: 10.1371/journal.pone.0058634

37. Shen A, Lupardus PJ, Gersch MM, Puri AW, Albrow VE, Garcia KC, et al. Defining an allosteric circuit in the cysteine protease domain of Clostridium difficile toxins. Nat Struct Mol Biol. (2011) 18:364-71. doi: 10.1038/nsmb. 1990

38. Lockner JW, Eubanks LM, Choi JL, Lively JM, Schlosburg JE, Collins KC, et al. Flagellin as carrier and adjuvant in cocaine vaccine development. Mol Pharma. (2015) 12:653-62. doi: 10.1021/mp500520r

39. Kimishima A, Wenthur CJ, Eubanks LM, Sato S, Janda KD. Cocaine vaccine development: evaluation of carrier and adjuvant combinations that activate multiple toll-like receptors. Mol Pharma. (2016) 13:3884-90. doi: 10.1021/acs.molpharmaceut.6b00682

40. Jank T, Belyi Y, Aktories K. Bacterial glycosyltransferase toxins. Cell Microbiol. (2015) 17:1752-65. doi: 10.1111/cmi.12533

41. Li S, Shi L, Yang Z, Feng H, et al. Cytotoxicity of Clostridium difficile toxin $\mathrm{B}$ does not require cysteine protease-mediated autocleavage and release of the glucosyltransferase domain into the host cell cytosol. Pathog Dis. (2013) 67:11-8. doi: 10.1111/2049-632X.12016

42. Lefeber DJ, Benaissa-Trouw B, Vliegenthart JF, Kamerling JP, Jansen WT, Kraaijeveld $\mathrm{K}$, et al. Th1-directing adjuvants increase the immunogenicity of oligosaccharide-protein conjugate vaccines related to Streptococcus pneumoniae type 3. Infect Immun. (2003) 71:6915-20. doi: 10.1128/IAI.71.12.6915-6920.2003 
43. Germann T, Bongartz M, Dlugonska H, Hess H, Schmitt E, Kolbe L, et al. Interleukin-12 profoundly up-regulates the synthesis of antigen-specific complement-fixing IgG2a, IgG2b and IgG3 antibody subclasses in vivo. Eur J Immunol. (1995) 25:823-9. doi: 10.1002/eji.1830250329

44. Ravetch JV, Kinet JP. Fc receptors. Annu Rev Immunol. (1991) 9:457-92. doi: 10.1146/annurev.iy.09.040191.002325

45. Bobat S, Flores-Langarica A, Hitchcock J, Marshall JL, Kingsley RA, Goodall $\mathrm{M}$, et al. Soluble flagellin, FliC, induces an Ag-specific Th2 response, yet promotes T-bet-regulated Th1 clearance of Salmonella typhimurium infection. Eur J Immunol. (2011) 41:1606-18. doi: 10.1002/eji.2010 41089

46. He X, Sun X, Wang J, Wang X, Zhang Q, Tzipori S, et al. Antibody-enhanced, Fc gamma receptor-mediated endocytosis of Clostridium difficile toxin A. Infect Immun. (2009) 77:2294-303. doi: 10.1128/IAI.01577-08

47. Miao EA, Andersen-Nissen E, Warren SE, Aderem A. TLR5 and Ipaf: dual sensors of bacterial flagellin in the innate immune system. Semin Immunopathol. (2007) 29:275-88. doi: 10.1007/s00281-007-0078-z

48. Jarchum I, Liu M, Lipuma L, Pamer EG. Toll-like receptor 5 stimulation protects mice from acute Clostridium difficile colitis. Infect Immun. (2011) 79:1498-503. doi: 10.1128/IAI.01196-10

49. Turley CB, Rupp RE, Johnson C, Taylor DN, Wolfson J, Tussey L, et al. Safety and immunogenicity of a recombinant M2e-flagellin influenza vaccine (STF2.4xM2e) in healthy adults. Vaccine (2011) 29:5145-52. doi: 10.1016/j.vaccine.2011.05.041

50. von Eichel-Streiber C, Sauerborn M, Kuramitsu HK. Evidence for a modular structure of the homologous repetitive C-terminal carbohydrate-binding sites of Clostridium difficile toxins and Streptococcus mutans glucosyltransferases. J Bacteriol. (1992) 174:6707-10. doi: 10.1128/jb.174.20.6707-6710.1992

51. Papatheodorou P, Barth H, Minton N, Aktories K. Cellular uptake and modeof-action of Clostridium difficile toxins. Adv Exp Med Biol. (2018) 1050:77-96. doi: 10.1007/978-3-319-72799-8_6

52. Manse JS, Baldwin MR. Binding and entry of Clostridium difficile toxin B is mediated by multiple domains. FEBS Lett. (2015) 589(Pt B):3945-51. doi: 10.1016/j.febslet.2015.11.017

53. Tao L, Zhang J, Meraner P, Tovaglieri A, Wu X, Gerhard R, et al. Frizzled proteins are colonic epithelial receptors for C. difficile toxin B. Nature (2016) 538:350-5. doi: 10.1038/nature19799

54. Gerhard R. Receptors and binding structures for Clostridium difficile toxins A and B. Curr Top Microbiol Immunol. (2017) 406:79-96. doi: 10.1007/82_2016_17

Conflict of Interest Statement: The authors declare that the research was conducted in the absence of any commercial or financial relationships that could be construed as a potential conflict of interest.

Copyright (c) 2018 Wang, Wang, Cai, Kelly and Sun. This is an open-access article distributed under the terms of the Creative Commons Attribution License (CC BY). The use, distribution or reproduction in other forums is permitted, provided the original author(s) and the copyright owner(s) are credited and that the original publication in this journal is cited, in accordance with accepted academic practice. No use, distribution or reproduction is permitted which does not comply with these terms. 